\title{
Vale Alison Lee
}

\section{ROSIE WICKERT}

Literacy educators world-wide will be saddened to hear of the death of Professor Alison Lee following a tough struggle with pancreatic cancer. Alison has been one of the editors of Literacy and Numeracy Studies since 1994 and her commitment to ensuring its quality and its future will be much missed.

Alison's interest in literacy education goes back many years, starting with her early career as a secondary school English teacher. She soon moved into higher education as a literacy adviser for undergraduate students, from whence began her long standing research interest in literacy, pedagogy and knowledge-making. Her PhD study of gender, literacy and curriculum politics was recognized as outstanding by the Australian Association of Research in Education and was published in book form by Routledge soon after. After joining UTS in 1992, Alison's interest in literacy pedagogy extended to numeracy and it was through her early publications in Literacy and Numeracy Studies that many became familiar with Alison's distinctive approach.

I know Alison as doctoral supervisor, co-author, co-editor, co-teacher and above all as friend. She changed my life as she opened the door to other ways of seeing and understanding literacy and its interconnections with the world. Team teaching alongside her was a wonderful experience.

Alison is perhaps best known for her passionate interest in the pedagogy of doctoral education, for which she holds a national citation from the Australian Learning and Teaching Council (ALTC). With Carolyn Williams, an early (1999) article Forged in Fire: Narratives of Trauma in PhD Supervision Pedagogy immediately connected with the travails of doctoral students and gave them a sense of community. Since then she published widely on doctoral supervision, research writing and the changing nature of the doctorate. Her publication record in these areas is matched only with the consistently warm and generous support she offered to so many doctoral students in Australia. I recall how her workshops on academic writing revolutionized not only how participants understood what they were trying to achieve in their writing, but also how academic literacy support was conceptualized.

Alison's relationship with many of her doctoral students was 'bothways'. They led her into their worlds too. Her interest in professional learning, such as the pedagogies of health was a more recent interest - in 
particular the complex issues of implementing and sustaining change to professional practice.

Without question, Alison was a life-changer. Not perhaps a term she would welcome but, as others have acknowledged, she changed the way many think about and theorise literacy and doctoral study. It is hard to reconcile with the fact that she has gone. But her truly impressive publication record ensures that she lives on.

Vale Alison. You are much loved and will be much missed. 